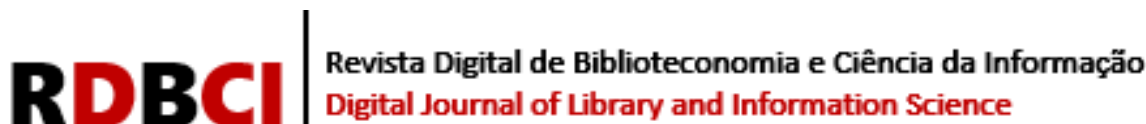

$\mathbf{I S T}_{1678-765 x}$

do

10.20396/rdbci.v19ioo.8665764 (c) (i) BY

ARTIGO DE PESQUISA

\section{A responsabilidade social dos bibliotecários em bibliotecas públicas dimensões e ações}

\author{
Fernanda Bernardo Ferreira ${ }^{1}$ iD https://orcid.org/0000-0003-1135-5141 \\ Sandra de Albuquerque Siebra 2 iD https://orcid.org/0000-0002-0078-6918 \\ ${ }^{1}$ Universidade Federal de Pernambuco, Recife, PE, Brasil / e-mail: nandabernardo@yahoo.com.br \\ ${ }^{2}$ Universidade Federal de Pernambuco, Recife, PE, Brasil / e-mail: sandra.siebra@ufpe.br
}

\begin{abstract}
RESUMO
Introdução: A responsabilidade social consiste na atuação e no compromisso do profissional em proporcionar serviços e realizar ações voltados às necessidades de seus usuários e à produção de resultados que beneficiem a toda comunidade alvo. Objetivo: O objetivo geral deste artigo é analisar as dimensões e ações relacionadas à responsabilidade social desenvolvidas por bibliotecários em bibliotecas públicas. Metodologia: Caracteriza-se como uma pesquisa descritiva, quali-quantitativa, bibliográfica e documental. Também foram coletados dados em três bibliotecas públicas na cidade do Recife, usando um questionário enviado aos bibliotecários destas bibliotecas através de e-mail. Adicionalmente foram mapeadas atividades e serviços ofertados remotamente, por meio do uso das redes sociais das bibliotecas, durante o período da pandemia do Covid-19, que provocou a suspensão das atividades, a partir de março/2020. Aos dados coletados foi aplicada a análise de conteúdo. Resultados: Como resultado foi realizado o mapeamento de dimensões e ações da função social das bibliotecas relacionadas à responsabilidade social, com base no referencial teórico, em análise documental e na análise dos questionários aplicados às bibliotecas estudadas. Conclusão: Verifica-se que a maioria das práticas de responsabilidade social mapeadas já fazem parte do fazer bibliotecário e que as dimensões ética, política, educacional e cultural contempladas nas atividades biblioteconômicas são abrangidas naquelas dimensões e ações. Logo, a partir dos resultados obtidos, considera-se que é notória a responsabilidade social do bibliotecário e, também, da biblioteca pública enquanto espaço propício à promoção da leitura e da cidadania, ao incentivo da cultura, e à inclusão social e digital.
\end{abstract}

PALAVRAS-CHAVE

Serviços de biblioteca. Bibliotecas públicas. Responsabilidade social do bibliotecário. Promoção do uso da biblioteca. Inclusão social.

\section{Librarians' social responsibility in public libraries dimensions and actions}

\begin{abstract}
Introduction: Social responsibility consists of the professional's performance and commitment to provide services and perform actions aimed at the needs of its users and the production of results that benefit the entire target community. Objective: The general objective of this article is to analyze the dimensions and actions related to social responsibility developed by librarians in public libraries. Methodology: It is characterized as a descriptive, quali quantitative, bibliographic and documental research. Data were also collected in three public libraries in the city of Recife, using a questionnaire sent to the librarians of these libraries via e-mail. Additionally, activities and services offered remotely were mapped, through the use of the libraries' social networks, during the period of the Covid-19 pandemic, which caused the suspension of the activities, starting in March/2020. Content analysis was applied to the
\end{abstract}




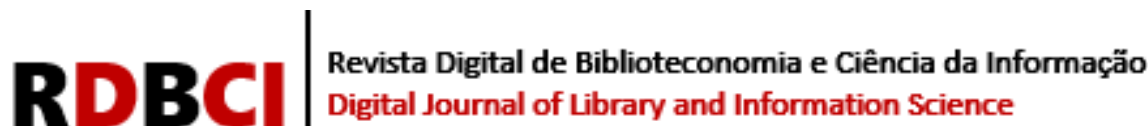

collected data. Results: The result was the mapping of the dimensions and actions of the social function of libraries related to social responsibility, based on the theoretical framework, on document analysis and on the analysis of the questionnaires applied to the libraries studied. Conclusion: It is concluded that most of the mapped social responsibility practices are already part of librarianship and that the ethical, political, educational and cultural dimensions contemplated in librarianship activities are covered in those dimensions and actions. Therefore, it is notorious the social responsibility of the librarian and also of the public library as a space conducive to the promotion of reading and citizenship, the encouragement of culture, and social and digital inclusion.

\section{KEYWORDS}

Library services. Public libraries. Librarian's social responsibility. Promotion of library use. Social inclusion.

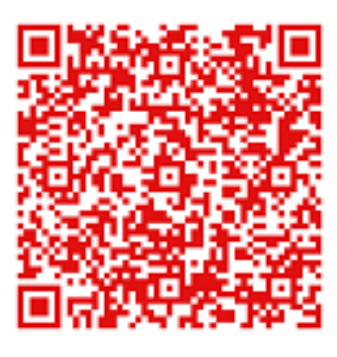

JITA: DC. Public libraries. 


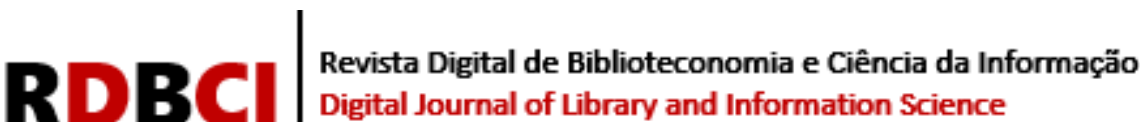

\section{INTRODUÇÃO}

A biblioteca, de acordo com Milanesi (2013) surgiu com o intuito de contribuir na organização do que era produzido e do conhecimento armazenado. Ainda segundo o autor, a função da existência da biblioteca está em facilitar a busca pelo que se quer encontrar na organização proposta nestes ambientes informacionais, garantindo a eficiência na oferta de seus serviços.

Diante das transformações sociais e tecnológicas que marcam a sociedade atual, a biblioteca tem, cada vez mais, precisado adaptar-se para potencializar e ofertar serviços e produtos inovadores, adequados e de qualidade, com o intuito de um atendimento eficaz aos seus usuários (BERNARDINO; SUAIDEN, 2011). E, na execução desses serviços e oferecimento de produtos, uma característica fundamental é a responsabilidade social (RS), que consiste na atuação e no compromisso do profissional bibliotecário em proporcionar ações voltadas às melhorias e em produzir resultados que beneficiem a todos (MORAES; LUCAS, 2012), em especial a comunidade atendida. O que se torna relevante especialmente para bibliotecas públicas que são, conforme Barros (2002, p.129), um “espaço público que tem como função democratizar e estimular a cultura na sociedade, um lugar onde os cidadãos socializam seus saberes e trocam experiências". O que é complementado por Bernardino e Suaiden (2011, p. 31), quando afirmam que "o papel social da biblioteca pública é permeado pelo acesso e disponibilidade da informação". Assim, a biblioteca pública deve ser vista como um lugar propício à construção do saber, da informação e do conhecimento; e de promoção de debates sobre as demandas sociais presentes em seu entorno. O que pode proporcionar que a biblioteca se torne verdadeiramente um espaço dinâmico, atrativo, de livre acesso à leitura e à informação, que pode conduzir ao conhecimento e à realização de ações de cunho social e cultural.

Neste cenário, esta pesquisa partiu do seguinte questionamento: quais são as práticas de Responsabilidade Social realizadas pelos bibliotecários, atuando em Bibliotecas Públicas, considerando as dimensões éticas, políticas, educacionais e culturais desempenhadas nas atividades Biblioteconômicas? E teve como objetivo geral analisar as dimensões e ações relacionadas à responsabilidade social desenvolvidas por bibliotecários em bibliotecas públicas.

Essa pesquisa se enquadra no contexto da Ciência da Informação (CI) pois, segundo Saracevic (1996, p. 41), a CI é vista como um campo que engloba "tanto a pesquisa científica, quanto a prática profissional, pelos problemas que propõe e pelos métodos que escolheu ao longo do tempo, para solucioná- los". Mais especificamente, ela coaduna com a dimensão social da CI, ressaltada por, entre outros autores, Saracevic (1996), Le Coadic (2004), Araújo (2009) ao explicitarem as práticas voltadas ao acesso, disseminação e uso eficaz da informação em diferentes situações e contextos, como forma de contribuir na inclusão, socialização e no desenvolvimento científico e social da sociedade.

Os resultados dessa pesquisa possibilitam reflexões sobre a ética, a responsabilidade social e sobre o papel social das bibliotecas, assim como apresentam possibilidades de ações e atividades a serem desenvolvidas em bibliotecas públicas em prol da cultura, da ética, da educação, da cidadania e bem estar social da comunidade atendida. O que pode proporcionar que os bibliotecários possam ir além das funções profissionais/técnicas que exercem, realmente inserindo-se na realidade da comunidade da qual a biblioteca faça parte. 


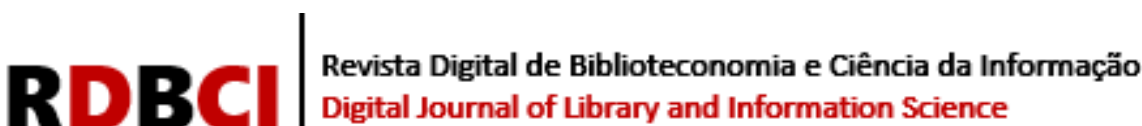

\section{A RESPONSABILIDADE SOCIAL}

O termo responsabilidade social (RS) tem sua primeira aparição em uma publicação nos Estados Unidos, tendo como autor Howard Bowen, nos anos 1950, no período pós- guerra mundial (ASHLEY, 2003). A partir da década de 1950, as empresas expandiram a visão em torno da prática efetiva de RS relacionando-a com proporcionar melhorias para as problemáticas existentes. Lourenço e Schroder (2003) veem a RS como responsabilidades para com a sociedade, onde a corporação desenvolve não apenas suas obrigações legais e econômicas, mas participa de todos os processos que envolvem empresa, funcionários e clientes.

O aumento da aplicação da RS ocorreu devido a inúmeros fatores, como por exemplo: a globalização e os avanços tecnológicos, que possibilitaram o conhecimento acerca das decisões desenvolvidas pelas organizações. E, também, pelos diversos tipos de exclusão, desemprego, fatores ambientais e desigualdades sociais que se tornaram evidentes, principalmente nas áreas menos desenvolvidas e esquecidas pelos governantes (ABNT, 2010).

Assim, o conceito de responsabilidade social se tornou abrangente, permitindo que os sujeitos compreendam a presença da ética e da moral na atuação ética e socialmente responsável. Como consequência, a RS abarcou diversificados ambientes da sociedade, deixando de circular apenas nos ambientes empresariais e tornou-se parte das esferas educacionais, adentrando no espaço das bibliotecas e, consequentemente, nas atividades dos profissionais da informação.

\subsection{Responsabilidade Social e Ética}

Para Vijesh e Mohanan (2018, p. 82) "a RS é uma estrutura ética que sugere que uma entidade, seja ela organização ou indivíduo tem a obrigação de agir para beneficiar a sociedade em geral". Considerando, desta forma, que todos somos responsáveis por condutas éticas e conscientes. O que é endossado por Du Mont (1991) quando define a RS como um conceito ético, responsável por modificações, e que prioriza as necessidades humanas e a forma de suprilas. Para o autor, a RS refere-se ao compromisso e cumprimento ético e legal de atividades. Logo, a relação da ética com à RS tem como objetivo contribuir para a melhoria de ações, permitindo englobar não apenas valores morais (FERREIRA, 2015). Assim, a RS envolve modificações em relação às necessidades humanas, de diferentes tipos, que devem ser atendidas, enfatizando "uma preocupação com as dimensões sociais do serviço de informação que tem a ver com a melhoria da qualidade de vida" (VIJESH; MOHANAN, 2018, p. 82).

Em 2010, foi publicada pela Associação Brasileira de Normas Técnicas (ABNT) a ISO 26000 (2010) que visou instituir-se como um guia para as organizações que querem desenvolver ações responsáveis. Ela valoriza a RS, ao enfatizar suas ações, além de questões legais e suas obrigações, envolvendo os valores éticos e morais presentes na sociedade. A ABNT ISO 26000 (2010) estabelece princípios que norteiam as atividades organizacionais, levando em conta as diversidades culturais, políticas, econômicas e sociais de cada comunidade, de forma a nutrir uniformidade com as normas internacionais.

\subsection{Dimensões da Responsabilidade Social}

Conforme a ABNT ISO 26000 (2010), são consideradas empresas socialmente responsáveis aquelas que buscam um olhar abrangente sobre os diversificados aspectos que a 


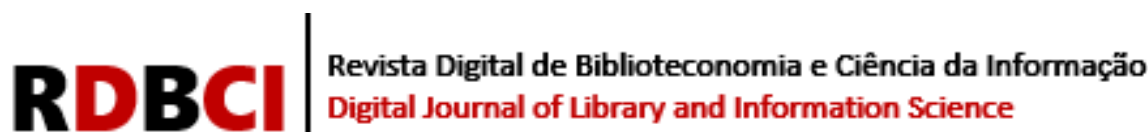

compõem. Assim, a chamada responsabilidade social empresarial (RSE), é definida pelo Conselho Empresarial Mundial para o Desenvolvimento Sustentável (World Business Council for Sustainable Development - WBCSD) como o compromisso contínuo da empresa se comportar de forma ética e, ao mesmo tempo, tanto contribuir para o desenvolvimento econômico de sua região, quanto para a melhoria da qualidade de vida dos funcionários, de suas famílias, da comunidade local e da sociedade em geral (FLAHERTY, 1998; COOK; GELDENHUYS, 2018). Dahlsrud (2008) afirmou que a RSE é uma construção social e, ao estudar as semelhanças e diferenças entre as várias definições existentes na época, apontou que elas se referem basicamente a cinco dimensões: ambiental, social, econômica, voltada para as partes interessadas e voluntariado. Essas dimensões, que foram posteriormente adaptadas e descritas por Cook e Geldenhuys (2018), estão resumidas no Quadro 1.

\begin{tabular}{|c|l|}
\hline \multicolumn{2}{|c|}{ Quadro 1. Cinco dimensões de Dahlsrud para a RSE. } \\
\hline DIMENSÃO & \multicolumn{1}{c|}{ DESCRIÇÃO } \\
\hline Ambiental & $\begin{array}{l}\text { Remete à ideia de impacto ambiental, de um ambiente limpo, do uso } \\
\text { feito dos recursos naturais. }\end{array}$ \\
\hline Social & $\begin{array}{l}\text { Remete à relação entre a empresa/instituição e a sociedade, com foco } \\
\text { em contribuir para uma sociedade melhor, integrando as preocupações } \\
\text { com o social nas atitudes/ações empresariais. }\end{array}$ \\
\hline Econômica & $\begin{array}{l}\text { Abrange aspectos sócio econômicos ou financeiros com foco em } \\
\text { contribuir com o desenvolvimento econômico da empresa, visando a } \\
\text { lucratividade. }\end{array}$ \\
\hline Voltada para as partes interessadas & $\begin{array}{l}\text { Remete à necessidade de interação com e entre as partes interessadas; } \\
\text { à forma como a empresa interage com empregados, fornecedores, } \\
\text { usuários/clientes e com a comunidade. }\end{array}$ \\
\hline Voluntariado & $\begin{array}{l}\text { Remete ao fato da empresa ir além das obrigações legais, com base em } \\
\text { valores éticos. }\end{array}$ \\
\hline \multicolumn{1}{|c|}{ Fonte: baseado em Cook; Geldenhuys (2018). }
\end{tabular}

Carroll (1979) e Machado Filho (2013) destacam as dimensões sociais da responsabilidade social nas empresas e ampliam a visão para sua prática em todas as áreas da sociedade. Conforme estes autores, o conceito de RS abarca quatro dimensões: econômica, legal, ética e discricionária, conforme pode ser visualizado na Figura 1.

Figura 1. Dimensões da Responsabilidade Social

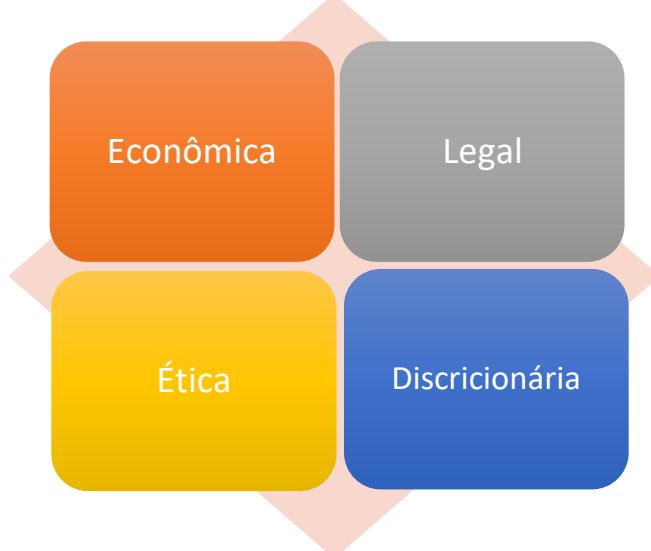

Fonte: baseado em Machado Filho (2013). 


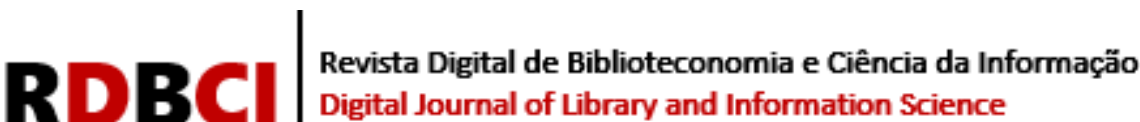

De acordo com Carroll (1979) e Machado Filho (2013), a dimensão econômica é a mais importante das dimensões, tendo como foco a responsabilidade de produzir bens e produtos voltados à sociedade com fins lucrativos. A RS conduz mudanças, mas pode colaborar com uma visão estrategista de sua visibilidade, uma vantagem competitiva que favorece sua boa imagem no meio organizacional (PAULA, 2010). A dimensão legal refere-se à responsabilidade que articula as leis e os regulamentos presentes nas instituições, sendo sua execução realizada de forma simultânea. As leis são incluídas no convívio da sociedade e das empresas com o intuito de que, sendo aceitas, padrões de conduta sejam estabelecidos e seguidos, contribuindo com a segurança e integridade das ações realizadas (FERREL, 2001). A dimensão ética promove a reflexão e a compreensão dos valores para a sociedade, para a empresa e também para todos que compõem as instituições. Segundo Carroll (1979), há comportamentos e atividades que não são apresentados nos regulamentos que regem empresas e sociedades, mas que são esperados pelos membros das instituições e da comunidade.

Carroll (1979, p. 500) relata que "existem expectativas da sociedade para que as empresas assumam papéis sociais", o que é destacado pela dimensão discricionária, que está voltada a filantropia. Entendemos, portanto, que as responsabilidades econômica e legal estão ligadas às obrigações de uma empresa de gerar lucro para os acionistas e cumprir as leis e os regulamentos estabelecidos. Já as responsabilidades ética e discricionária abrangem o comprometimento dos recursos da empresa com iniciativas a fim de melhorar a comunidade (CARROLL; SHABANA, 2010).

No entendimento de Dantas e Garcia (2013, p. 4) "as funções desempenhadas pela biblioteca contribuem para a construção dos indícios de RS na CI e suas teorias e práticas". Dessa forma, nesta pesquisa a reflexão recaiu sobre a RS no contexto das bibliotecas públicas, visto que assim como as empresas socialmente responsáveis, as bibliotecas públicas possuem em suas ações as dimensões econômicas, legal, ética e discricionária, que são exploradas na próxima seção.

\section{A BIBLIOTECA PÚBLICA: ESPAÇO DE CONSTRUÇÃO SOCIAL}

De acordo com o Manifesto da Federação Internacional das Associações e Instituições Bibliotecárias (IFLA), elaborado em 1994, a biblioteca pública é definida como “[...] porta de acesso local ao conhecimento - fornece as condições básicas para uma aprendizagem contínua, para uma tomada de decisão independente e para o desenvolvimento cultural dos indivíduos e dos grupos sociais" (IFLA, 1994, p.1). Nesse sentido, a biblioteca apresenta um papel fundamental e necessário, por abranger diversificados públicos e, também, por contribuir com diferentes usos das informações nela encontradas. Assim, ela coaduna com o pensamento de Ranganathan (2009), ao afirmar em sua quinta lei que a biblioteca é um organismo vivo e crescente, o que destaca o seu papel social e ativo, que com tal vivacidade permite ser presente nas inúmeras áreas: social, cultural, econômica e histórica.

As mudanças sociais e tecnológicas ocorridas no mundo atual refletem significativamente nas bibliotecas públicas, pois, como afirmam Bernardino e Suaiden (2011, p. 31), "o papel social da biblioteca pública é permeado pelo acesso e disponibilidade da informação" e estes vêm se modificando no decorrer do tempo. E neste cenário dinâmico, o papel social da biblioteca pública e sua relevância, conforme Tello (2013), não está presente apenas em seu acervo, mas no crescimento e enriquecimento da sociedade por meio dos inúmeros serviços por ela ofertados. 


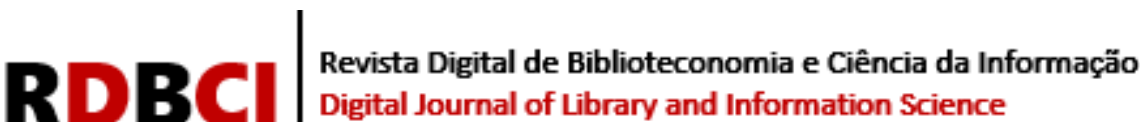

\subsection{Dimensões da Função Social da Biblioteca Pública}

Dentre as dimensões apresentadas por Ferraz e Dumont (2018) como essenciais na biblioteca pública, como fundamentais para cumprir a sua função social estão: o acervo, os serviços ofertados, o incentivo à leitura, a preservação da memória, a disponibilização da informação, a biblioteca como lugar de aprendizado, o acesso às tecnologias, o conhecimento da comunidade, a interlocução com esta, a biblioteca como espaço de encontro, a construção cidadã e o por último a importância do perfil bibliotecário.

Romero-Sanchés, Gómes-Hernández e Hernández-Pedreño (2019) apresentam as dimensões da função social da biblioteca caracterizando- as conforme seu principal objetivo, englobando acesso, ações culturais e sustentabilidade. Outra forte dimensão social da biblioteca pública está na disseminação informacional, que permite o incentivo à leitura, a participação cidadã, o uso do espaço, o conhecimento de seus deveres e direitos, a preservação da memória local e de sua própria história. O que é endossado por Machado, Elias Junior e Achiles (2014, p. 124) que consideram necessário "levar em consideração todos os elementos constituintes dessa configuração social, política, econômica e cultural", ao se pensar na biblioteca pública na sociedade da informação.

Refletir sobre as dimensões sociais que regem as bibliotecas públicas nos faz considerar os diversos elementos sociais e externos que as constituem, além de sobre a função social que desempenham com o objetivo principal de possibilitar melhorias e crescimento a seus usuários. De fato, Barros (2002) corrobora com a contribuição do papel das bibliotecas na ampliação dos sentidos e das ações na vida social de todos os atores envolvidos, favorecendo o crescimento e compreensão acerca das inúmeras situações da sociedade. Além disso, seu caráter público garante o acesso livre e ela caracteriza-se principalmente por atender e incluir todos os tipos de públicos, o que favorece a inclusão nos diversificados contextos, seja cultural, informacional, tecnológico e físico. Destaca-se também o papel realizado nas bibliotecas em relação à questão ambiental, a conscientização de seus usuários por um ambiente sustentável, o que permite a construção ética em diversificados pontos.

\subsection{Bibliotecas Públicas, Responsabilidade Social e Ética do Bibliotecário}

Diante da conceituação sobre RS e biblioteca pública, autores como Romero-Sánchez, Gómez-Hernández e Hernández-Pedreño (2019) e Bernardino e Suaiden (2011) definem a responsabilidade social presente nas bibliotecas públicas ao conceituar suas ações relacionadas à inclusão digital, à disseminação da informação, à cultura, à sustentabilidade e ao conhecimento sobre a dimensão social da biblioteca e sobre a função social do bibliotecário e da biblioteca.

Inúmeras são as contribuições das bibliotecas públicas que se fazem presentes no contexto da sociedade e tornam-se importantes no processo de transformação das comunidades atendidas, onde a leitura, as atividades culturais, a socialização, a inclusão e a oferta de serviços adequados favorecem o desenvolvimento crítico e cidadão. Porém, é preciso inserir as atividades de acordo com as necessidades da comunidade atendida, o que deve ser um trabalho construído diariamente e em conjunto com representantes da comunidade, de forma a construir uma relação de entrega e de abertura. Essa percepção amplia o olhar sobre o papel social e a RS das bibliotecas. Além disso, abrir a biblioteca ao convívio comunitário e mapear suas necessidades, além dos já citados benefícios, permite um ambiente de prevenção à violência e também de conscientização de que o espaço pertence a todos.

RDBCl: Rev. Dig. Bibliotec e Ci. Info. / RDBCl: Dig. J. of Lib. and Info. Sci.| Campinas, SP | v.19| e021022 | 2021 


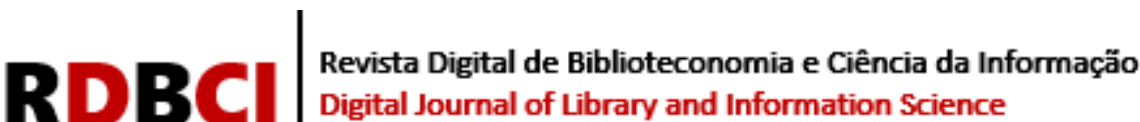

Discutir a relevância social da biblioteca pública nos dias atuais permite a ampliação de suas práticas, bem como a ressignificação deste ambiente no olhar dos profissionais e dos usuários que a frequentam. Assim, é preciso refletir sobre o papel do bibliotecário nesse contexto da responsabilidade social das bibliotecas públicas. Pois, de acordo com Pajo e Lee (2010), uma das maneiras pelas quais as instituições/empresas podem demonstrar sua responsabilidade social é incentivando e apoiando o envolvimento dos seus funcionários em programas e ações que envolvam a comunidade.

Conforme as autoras Mischiati e Valentim (2005), inúmeras modificações podem ocorrer na comunidade atendida, dependendo da realidade e das características de cada uma, e o profissional bibliotecário é o responsável pela prática e relevância da ética e da RS no convívio humano e nas suas condutas, observando a transformação da ética e dos valores de acordo com o tempo. Percebe-se, dessa maneira, que a ética vista como orientação do agir em sociedade também é levada para o âmbito profissional, o que permite a reflexão da ética bibliotecária expressa nas atividades diárias biblioteconômicas.

Nessa perspectiva, a ética, como afirma Du Mont (1991), fundamenta a atuação dos profissionais da informação com práticas de RS, onde permeia todas as profissões e também se faz presente nas práticas bibliotecárias. Ela é base primordial na construção das atividades que promovem tanto o bem estar social, quanto a melhoria das relações trabalhistas, tornando-se meio indissociável da prática responsável, o que contribui na busca por melhores estratégias e políticas a serem adotadas. Nesse ponto, pode-se afirmar que "a responsabilidade social é uma postura que deveria perpassar as atividades de quaisquer profissionais, entre elas, a do bibliotecário" (MORAES; LUCAS, 2012, p. 114).

Ressalta-se que, conforme afirmado por Moraes e Lucas (2012), a prática da responsabilidade social do bibliotecário (RSB) não é recente, visto que o próprio cuidado para com o acervo é uma ação responsável.

\section{METODOLOGIA}

Esta pesquisa caracteriza-se como descritiva, quali-quantitativa, bibliográfica e documental (KAUARK; MANHÃES; MEDEIROS, 2010). O levantamento bibliográfico foi realizado em livros, dissertações e teses (recuperadas em repositórios institucionais), além de em artigos recuperados em bases de dados como a Base de Dados em Ciência da Informação (BRAPCI) e Scientific Eletronic Library Online (SCIELO). A análise documental englobou documentos relacionados às leis e normativas que abordavam a temática de estudo, assim como foram analisados os documentos normativos e de descrição das atividades das bibliotecas selecionadas para o estudo.

Para uma melhor percepção da prática da RS nas bibliotecas públicas foram coletados dados em três biblioteca públicas da cidade do Recife, incluindo 1) a única estadual, a Biblioteca Pública Estadual de Pernambuco (BPE) localizada no bairro de Santo Amaro, que foi criada em 1841 e inaugurada em 5 de maio de 1852 (BPE, 2020). E duas municipais: 2) a Biblioteca Popular de Casa Amarela Jornalista Alcides Lopes, localizada no bairro de Casa Amarela foi fundada no ano de 1949 e reformada no ano de 2016. Faz parte da Rede de Bibliotecas Pela Paz pertencente à Secretaria de Segurança Urbana da Prefeitura da Cidade do Recife. 3) a Biblioteca Popular de Afogados Jornalista Ronildo Maia Leite, localizada no bairro de Afogados e inaugurada em 12 de janeiro de 1955. Esta também faz parte da Rede de Bibliotecas Pela Paz. Uma forte questão das bibliotecas públicas dessa rede está nas parcerias firmadas para a realização de suas ações, bem como o vínculo que é fortalecido quando permite que a comunidade seja parceira em seu espaço (RECIFE, 2020). 


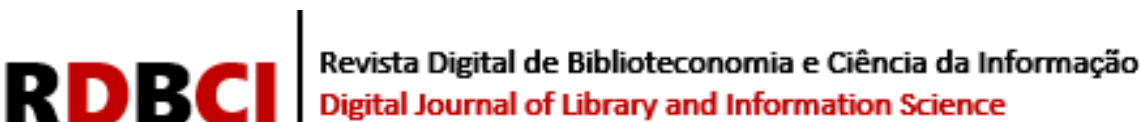

A coleta de dados foi realizada no período de março de 2020 a julho de 2020, por meio da análise dos documentos e normativas das bibliotecas, da observação dos serviços oferecidos remotamente (por causa do contexto da pandemia do COVID-19 que trouxe a necessidade de distanciamento social e, consequente, suspensão das atividades presenciais das bibliotecas) e do uso feito pelas bibliotecas selecionadas das redes sociais. Além da aplicação de questionário, enviado via e-mail após contato telefônico, aplicado aos Bibliotecários atuantes nas bibliotecas do estudo. Os sujeitos da pesquisa foram identificados com a letra B acrescida de um numeral $(01,02, \ldots)$ em ordem sequencial de 01 a 12 , correspondendo ao total dos respondentes do questionário, ficando assim, B01, B02, etc.

Para análise dos dados coletados utilizou-se a análise de conteúdo, definida por Bardin (2009), que permitiu a categorização, por ela privilegiar a subjetividade individual e grupal tornando-se uma ferramenta útil à interpretação da realidade social presente na pesquisa.

Para a realização da análise foram executadas as seguintes fases (FRANCO, 2005; BARDIN, 2009):

$\mathrm{Na}$ fase da pré-análise foi realizada a partir das leituras flutuantes de textos, artigos e dissertações relacionadas à RS, dimensões da RS e função social da biblioteca pública e ética do bibliotecário, tendo como foco pontos que se relacionavam com o objetivo da pesquisa. Buscou-se nestas leituras identificar as dimensões da função social da biblioteca pública que pudessem dar origem às categorias iniciais de análise.

A definição das categorias de análise foi feita a partir das leituras realizadas nos textos completos ao final da revisão de literatura e do resultado da análise documental. Tomou-se como base as dimensões iniciais da responsabilidade social e função social da biblioteca pública existentes nos textos de Romero-Sánchez, Gómez-Hernández e Hernández-Pedreño (2019) e Ferraz e Dumont (2018). As categorias definidas nessa fase contribuíram para construção do questionário utilizado para coleta de dados, o que facilitou o processo de análise das respostas que foram encaixadas nas categorias criadas. Quando as respostas dadas não se encaixavam em uma categoria previamente existente, uma nova categoria era criada, dando origem a uma nova dimensão ou ação, o que poderá ser visualizado na seção de resultados e discussões.

A última fase foi o tratamento dos resultados e a interpretação dos dados obtidos onde foram criados quadros, gráficos e figuras com o intuito de possibilitar uma melhor visualização dos resultados da análise. Na sequência, estes elementos foram discutidos à luz do referencial teórico. Em alguns momentos, as falas dos sujeitos da pesquisa que endossassem a discussão foram destacadas.

\section{RESULTADOS E DISCUSSÕES}

No total, 12 bibliotecários participaram da coleta de dados. Sendo 9 (nove) do sexo feminino e 3 (três) do sexo masculino. A faixa etária predominante foi de 30 a 50 anos. Quanto à formação, 8 (oito) bibliotecários possuíam apenas graduação e 4 (quatro) possuíam especialização. Quanto ao tempo de serviço como bibliotecário, 9 pessoas trabalham como bibliotecários há entre 5 e 10 anos, e os outros três trabalham como bibliotecários há mais de 20 anos. Em relação ao vínculo empregatício apenas duas possuem cargo comissionado e os demais todos são bibliotecários concursados.

A primeira questão do questionário estava relacionada à compreensão do conceito de responsabilidade social por parte dos bibliotecários. Os respondentes fizeram referência ao papel transformador e social que o profissional bibliotecário realiza, como identificado na fala "Relaciona-se com ser agente transformador da sociedade e promover o acesso informacional do cidadão" (B06). E destacaram principalmente a relação com a inclusão dos cidadãos, seja 


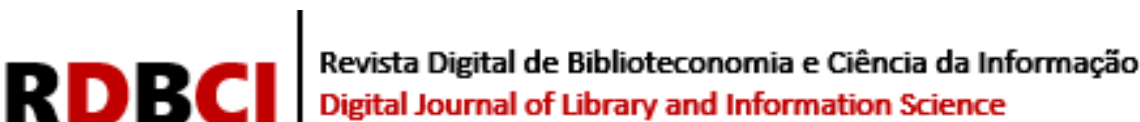

ela inclusão social ou digital, como endossado nas falas a seguir: "A responsabilidade social se refere a incluir o cidadão na sociedade da informação através dos serviços biblioteconômicos" (B02). "Refere-se a favorecer e contribuir para que a informação seja instrumento de inclusão social” (B07). Isto endossa o afirmado por Moraes e Lucas (2012) que a RS está presente em inúmeras funções bibliotecárias. Os bibliotecários também enalteceram o respeito às diferenças, e apontaram o benefício desta prática na sociedade, como destacado na fala "A responsabilidade social refere-se a respeitar as diferenças individuais e coletivas" (B01). O que relaciona-se com a ética e a cidadania e coaduna com o afirmado por Du Mont (1991) que a ética fundamenta as ações de RS de forma a garantir direitos e deveres.

Outra questão verificou que $92 \%$ dos bibliotecários já realizaram ou realizam atendimento de pessoas com deficiência. O que remete à questão da acessibilidade em seus mais variados contextos, sendo essa uma das funções da RS e da biblioteca pública: o de promover informação, acesso, cultura e lazer a todos, independente de limitações, conforme pontuado por Romero-Sánchez, Gómez-Hernández e Hernández-Pedreño (2019). A acessibilidade está ligada à RS, o que se relaciona de forma direta com as políticas públicas e a dimensão ética presente tanto na RS como na responsabilidade social da biblioteca. $\mathrm{O}$ atendimento às pessoas com deficiência precisa estar presente em diferentes segmentos das atividades biblioteconômicas: na forma de disponibilização das informações e acervos; na preparação para o atendimento adequado (por exemplo, atendimento na Língua Brasileira de Sinais -LIBRAS); na adaptação da estrutura física (ex: largura das portas, elevadores, rampas de entrada, etc) e nas plataformas digitais adotadas (ex: site com acessibilidade digital) pela biblioteca para atender a este público.

Outro ponto abordado foi a adequabilidade da formação do acervo da biblioteca pública para o público alvo (sua comunidade/usuários), o que se configura como uma das funções fundamentais da biblioteca e requer atenção da instituição, visto que o acervo deverá contemplar às necessidades não apenas informacionais, mas educativas e de lazer da comunidade atendida. Vale ressaltar que este ponto foi considerado um desafio, devido a heterogeneidade do público que frequenta as bibliotecas públicas, além dos contextos e recursos financeiros diferentes para aquisição de acervo, além do fato que alguns materiais/acervos são recebidos por doação. Assim, todos os bibliotecários mencionaram que, nem sempre, o acervo existente mostra-se realmente adequado à comunidade atendida. O respondente B09 ainda enfatizou a falta de políticas públicas para atualização e modernização dos acervos das bibliotecas públicas (inclusive com a disponibilização de biblioteca digital de acesso remoto) como um dos entraves para se ter um acervo suficiente e adequado para atender a comunidade. O que pode prejudicar a função da biblioteca pública que, segundo Milanesi (2013) está em possibilitar acesso para todos e contribuir no processo de disseminação da informação.

Buscou-se também conhecer as parcerias, colaborações e estratégias utilizadas pelas bibliotecas para poder realizarem atividades e dinamizar seu espaço. Todas as bibliotecas estudadas tinham algum tipo de parceria. Verificou-se que, dependendo do setor e das ações a serem desenvolvidas as parcerias são efetivadas. Foi registrada a parceria de algumas bibliotecas com a comunidade na qual está inserida (ex: produtores locais, líderes comunitários, artistas locais, etc), com organizações não governamentais (ONG’s's), universidades, consulados (Alemanha, França e China), museus e espaços culturais, além de escolas públicas e particulares e editoras diversas. Buscar parcerias faz parte da função social da biblioteca, o que é endossado por Vijesh e Mohanan (2018, p. 83) quando afirmam que "uma biblioteca que é uma instituição social mantém relações com diversificados públicos e setores". A formação de parcerias proporciona os recursos financeiros ou o pessoal necessário para a efetivação de algumas ações, como as atividades socioculturais, ou até mesmo o material para realização de cursos, oficinas e eventos, constituindo-se em alternativas para o desenvolvimento de atividades diversas. 


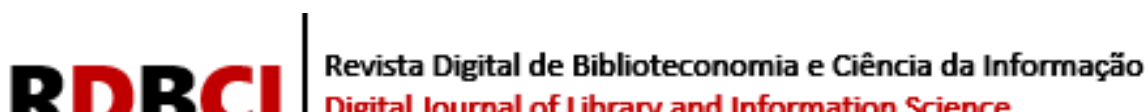 Digital Journal of Library and Information Science}

\subsection{Responsabilidade social e as Dimensões e Ações da Função Social das Bibliotecas Públicas}

No questionário havia algumas questões para mapear atividades realizadas diariamente, semanalmente, mensalmente e anualmente pelos bibliotecários nas bibliotecas públicas nas quais trabalham. Dentre as atividades diárias elencadas, como pode ser visualizado no Gráfico 1, o acesso, nas suas mais diversificadas maneiras, é apontado. Seja acesso à computadores, ao Wi-fi, à informação e/ou às leis e legislações por meio da internet, de livros ou revistas. Também foi apontada a questão ambiental como forma de conscientização e prática educativa, com a realização de ações como eliminação de copos descartáveis do dia a dia na biblioteca e a separação correta do lixo.

Gráfico 1. Categorias de ações realizadas nas bibliotecas diariamente

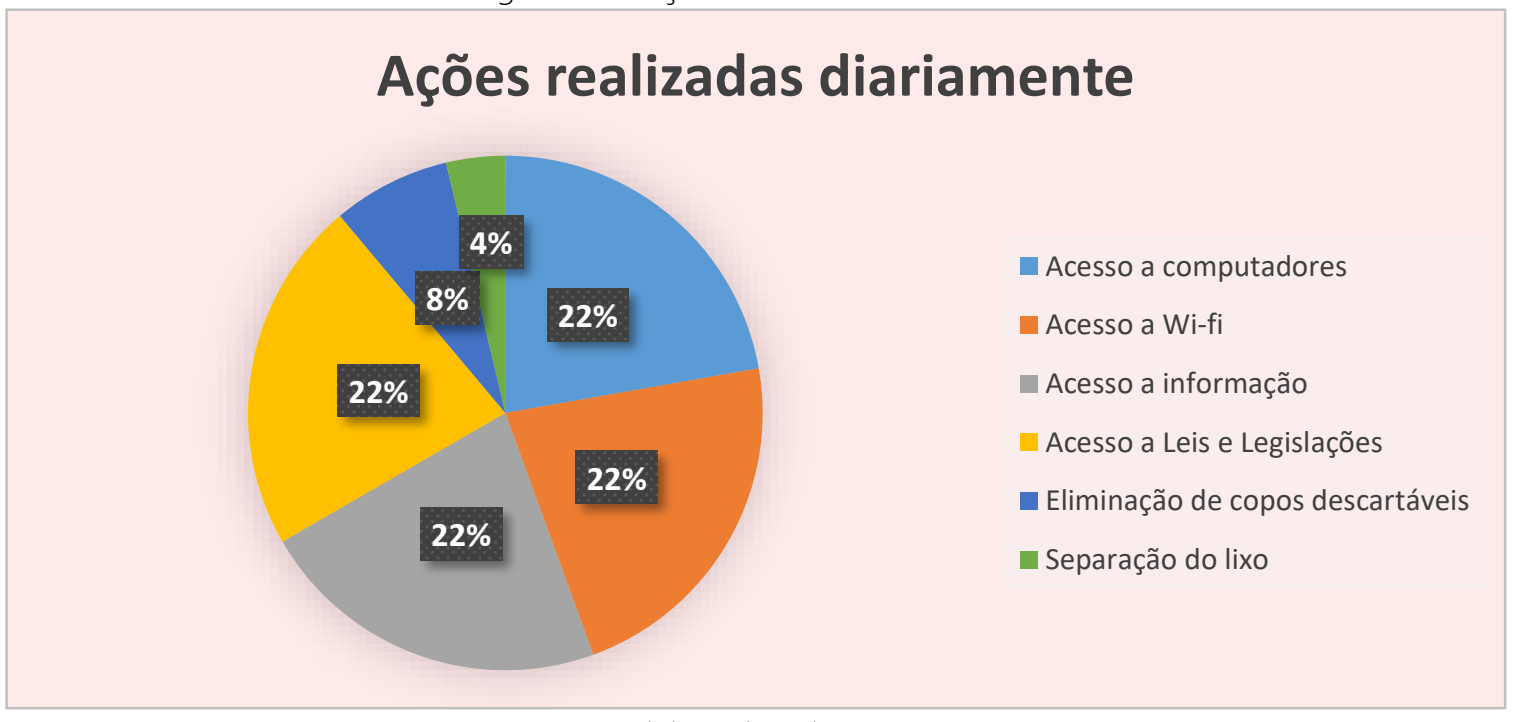

Fonte: elaborado pelas autoras, 2020.

O Quadro 2 apresenta as atividades desenvolvidas pelos bibliotecários em suas respectivas bibliotecas de forma semanal, mensal e anual.

Quadro 2. Atividades semanais, mensais e anuais realizadas nas bibliotecas

\begin{tabular}{|c|c|c|}
\hline ATIVIDADES SEMANAIS & ATIVIDADES MENSAIS & ATIVIDADES ANUAIS/PERIÓDICAS \\
\hline Hora do conto & Roda de Leitura & Aulas de informática \\
\hline Roda de Leitura & $\begin{array}{l}\text { Palestras e/ou roda de } \\
\text { conversa sobre temáticas } \\
\text { diversas }\end{array}$ & $\begin{array}{l}\text { Minicurso ou Cursos (artesanato, } \\
\text { profissionalizantes, temáticas } \\
\text { acadêmicas, etc) }\end{array}$ \\
\hline $\begin{array}{l}\text { Mini-curso ou Cursos } \\
\text { (artesanato, profissionalizantes, } \\
\text { temáticas acadêmicas, etc }\end{array}$ & $\begin{array}{l}\text { Eventos (seminários, mesas- } \\
\text { redondas, etc); }\end{array}$ & Apresentações de Teatro \\
\hline $\begin{array}{l}\text { Preparatórios para ENEM e/ou } \\
\text { Vestibular }\end{array}$ & $\begin{array}{l}\text { Campanhas sociais } \\
\text { (agasalhos, enchentes, natal, } \\
\text { etc) }\end{array}$ & Apresentações de Dança \\
\hline $\begin{array}{l}\text { Ações de cidadania (orientação } \\
\text { sobre e/ou emissão de } \\
\text { documentos, orientação jurídica, } \\
\text { etc) }\end{array}$ & Apresentações Musicais & Apresentações de Música \\
\hline
\end{tabular}




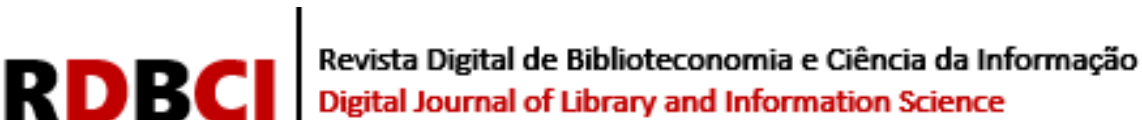

\begin{tabular}{|l|l|l|}
\hline $\begin{array}{l}\text { Ações de conscientização para } \\
\begin{array}{l}\text { com o Meio Ambiente (ex: coleta } \\
\text { seletiva de lixo, descarte correto } \\
\text { de óleo, etc) }\end{array}\end{array}$ & $\begin{array}{l}\text { Preparatórios para ENEM } \\
\text { e/ou Vestibular }\end{array}$ & $\begin{array}{l}\text { Ações de conscientização para com o } \\
\text { Meio Ambiente (ex: coleta seletiva de } \\
\text { lixo, descarte correto de óleo, etc) }\end{array}$ \\
$\begin{array}{l}\text { Amostras/ Exposições (livros, } \\
\text { objetos, poesias, trecho de livros, } \\
\text { sinopses, etc) }\end{array}$ & Reforço escolar & $\begin{array}{l}\text { Encontro de jogadores (ex: RPG, jogos } \\
\text { online, etc) }\end{array}$ \\
\hline
\end{tabular}

Fonte: elaborado pelas autoras, 2020.

Como pode ser visualizado no Quadro 2, dentre as atividades semanais destacadas pelos bibliotecários estão a Hora do Conto, as rodas de leitura, as amostras e exposições, e os preparatórios para o Exame Nacional do Ensino Médio (ENEM), além dos minicursos ou cursos de curta e média duração. Também foram destacadas as ações de cidadania e de conscientização e as visitas guiadas. Entre as atividades desenvolvidas mensalmente, conforme o planejamento das bibliotecas, são destacadas pela maioria dos respondentes as rodas de leitura, as palestras e/ou rodas de conversa, os eventos de diferentes tamanhos realizados no espaço que a biblioteca disponibiliza para este fim, a realização de campanhas sociais, as apresentações musicais e os preparativos do ENEM. Pertencentes à prática anual das bibliotecas e apontadas pela maior parte dos respondentes estão atividades relacionadas à aulas de informática, à realização de minicursos ou de cursos sobre temáticas diversas, além de apresentações de teatro, música e dança. Há também entre as atividades os encontros de jogadores, uma forma lúdica de socialização e de utilização do espaço, além da atividade de incentivo à leitura denominada troca-troca de livros. Ressalta-se que algumas dessas atividades não são exatamente anuais, são realizadas esporadicamente, pelo que foi possível perceber tanto em conversa com os gestores das bibliotecas, quanto em registros documentais das mesmas. Estas atividades possuem um intervalo de meses, sendo executadas, em média, de uma a três vezes ao ano. Supõe- se que, por isso, foram encaixadas pelos bibliotecários como atividades anuais.

Foi possível identificar que as ações realizadas pelos bibliotecários se alinhavam com as dimensões econômica, legal, ética e discricionária, previamente identificadas, uma vez que há a realização e prática de atividades que evidenciam as políticas públicas, o desenvolvimento cidadão, as questões sociais, o compromisso ético, dentre outras. A partir das falas dos bibliotecários, é possível observar que as atividades desenvolvidas nas bibliotecas colaboram com o desenvolvimento cultural, intelectual e de cidadania de seus usuários, pois elas trazem momentos reflexivos, de aprendizado e, também, de lazer e cultura. Isto é bastante relevante para a comunidade e contempla o apontado pela IFLA (1994) e por Bernardino e Suaiden (2011), que o espaço da biblioteca deve estar disposto a promover interações diversificadas, através do estímulo ao conhecimento, à cultura, à memória e ao livre acesso, o que foi observado na prática das bibliotecas estudadas. Além disso, com estas práticas, o bibliotecário pode contribuir, principalmente, na construção de ideias, na formação de cidadãos conscientes e no desenvolvimento da sociedade, permitindo que o usuário seja beneficiado em diversos sentidos, em relação a seus direitos e deveres, como também por meio da realização de atividades que colaborem na sua qualidade de vida, evidenciando um olhar completo sobre o indivíduo (FERREIRA, 2015). O que faz parte do papel social da Ciência da Informação. Vale destacar que a realidade de cada biblioteca e de cada bibliotecário tem suas particularidades. Assim, dependendo do contexto da biblioteca e do setor no qual o bibliotecário estava inserido, a forma de realização das ações é modificada. 


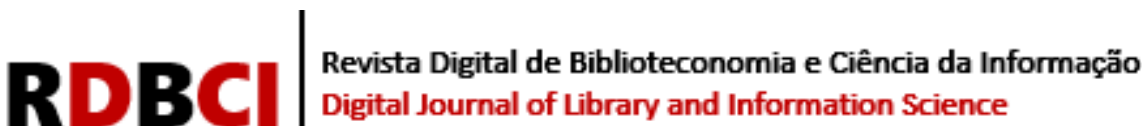

Considera-se que, para a realização das atividades mencionadas anteriormente, o usuário e a comunidade atendida devem ser vistos como o centro do planejamento, para que, além de sua participação efetiva, ocorra também a criação de um vínculo próximo e positivo em relação à biblioteca. Isto é destacado pelos autores que abordam a RS e a ética do bibliotecário, tais como Moraes e Lucas (2012) e pelo Conselho Federal de Biblioteconomia (2018), ao enfatizarem que a ação bibliotecária deve ser baseada na missão de proporcionar serviços de acordo com as demandas da comunidade. Ou seja, que busquem atender às necessidades e expectativas da comunidade em relação à biblioteca.

Após o mapeamento das ações indicadas pelos bibliotecários, verificou-se que muitas delas estão em consonância com as ações mapeadas a partir da revisão de literatura e da análise documental, trazendo alguns acréscimos para as categorias previamente identificadas. Assim, considerando: 1) que para Romero-Sánchez, Gómez-Hernández e Hernández-Pedreño (2019), a função social das bibliotecas públicas é ser por "essência social", uma vez que sua missão principal é promover a disseminação e o acesso à informação a todos sem restrições; 2) que os autores supracitados explicitamente pontuam dimensões da função social da biblioteca, textualmente em seu artigo, caracterizando-as conforme seu principal objetivo; estes autores foram tomados como base para a elaboração da Figura 2. Nela, a responsabilidade social está relacionada com as dimensões da função social da biblioteca. Na criação da figura, cada DIMENSÃO é representada em letra maiúscula e negrito e foi verificado que algumas ditas dimensões na literatura poderiam ser colocadas embaixo de outras e se caracterizavam mais como ações dentro da referida dimensão. Por exemplo, a dimensão ACESSO possui embaixo dela as ações Acesso ao Acervo e Acesso às Tecnologias. As ações foram representadas apenas com iniciais maiúsculas.

Dessa forma, na Figura 2, em amarelo estão as Dimensões apresentadas no trabalho de Romero-Sánchez, Gómez-Hernández e Hernández-Pedreño (2019) organizadas em Dimensões e Ações. Em roxo estão as Dimensões e Ações adicionadas a partir do levantamento bibliográfico e da análise documental, tendo sido utilizados autores como Almeida Júnior (2013), Alvin; Calixto (2013), Araújo (2009), Barros (2002), Bernardino e Suaiden (2011), Cook; Geldenhuys (2018), Cunha (2003), Cunha; Cavalcante ( 2008), Dahlsrud (2008), Du Mont (1991), Ferraz; Dumont (2018), IFLA (1994), Milanesi (2013), Moraes; Lucas (2012), Ranganathan (2009), Tello (2013) e Valls (2013).

Posteriormente, a partir da análise de conteúdo dos questionários aplicados, novas ações foram adicionadas à Figura 2 na cor laranja. E, por fim, as autoras sentiram necessidade de inserir as ações: "Capacitação Permanente", "Feedback da Comunidade", "Caixa de Sugestões" (apresentadas em azul), visto que, como mencionado por Ferraz e Dumont (2018), para desempenhar bem as suas atividades e cumprir com a sua função social o bibliotecário precisa estar atento a se manter atualizado, seja realizando cursos (mini cursos, cursos de extensão e capacitação, etc), quanto aprimorando sua formação acadêmica (especializações, mestrado, doutorado), além de estar atualizado quanto às polícias públicas que afetam o seu trabalho cotidiano ou à comunidade circunscrita. 


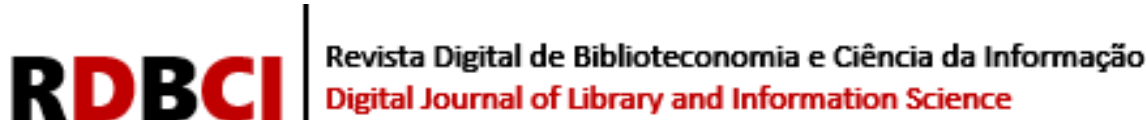

Figura 2. Responsabilidade social e as Dimensões e Ações da Função Social das Bibliotecas Públicas -

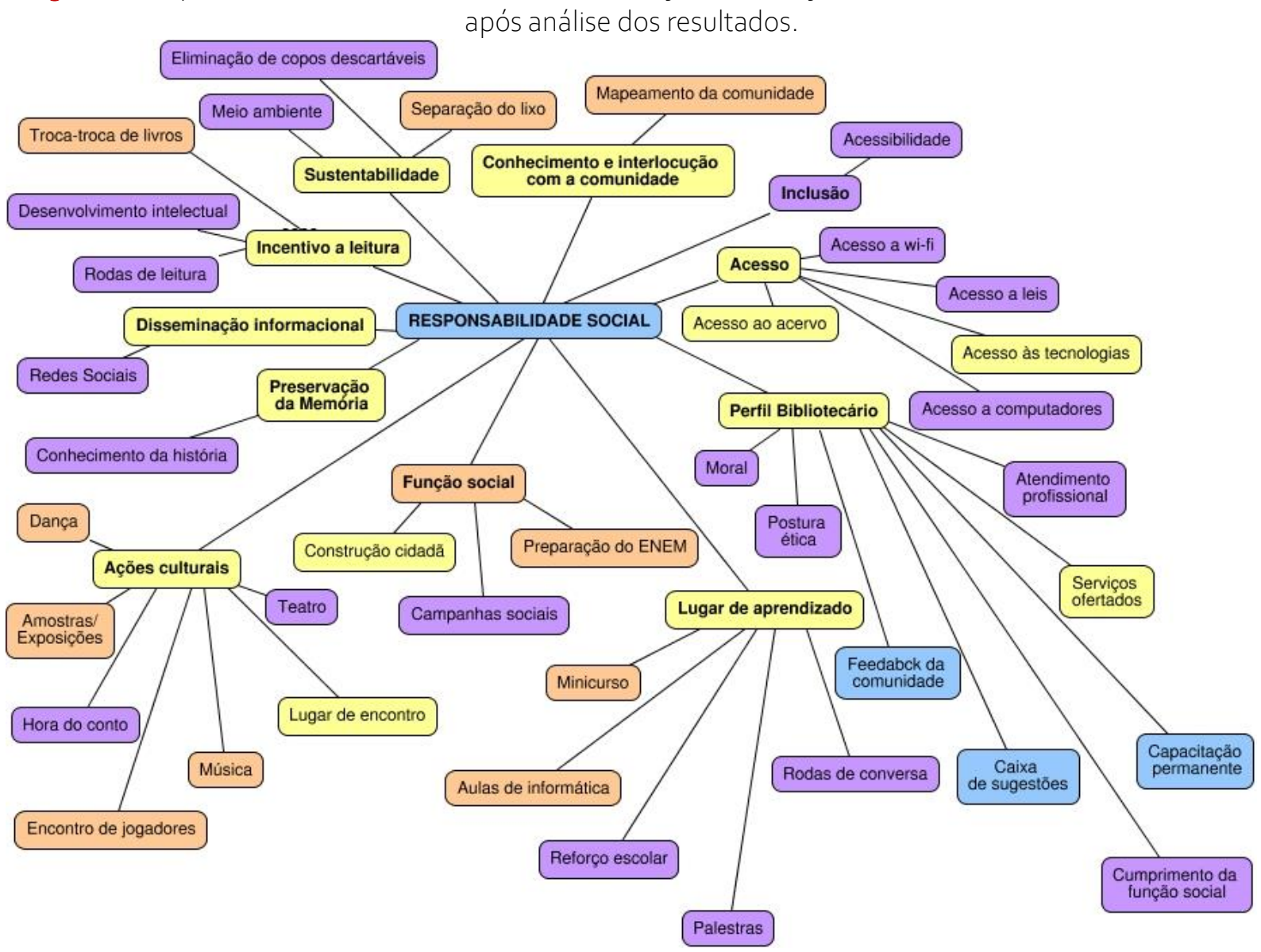

Legenda:

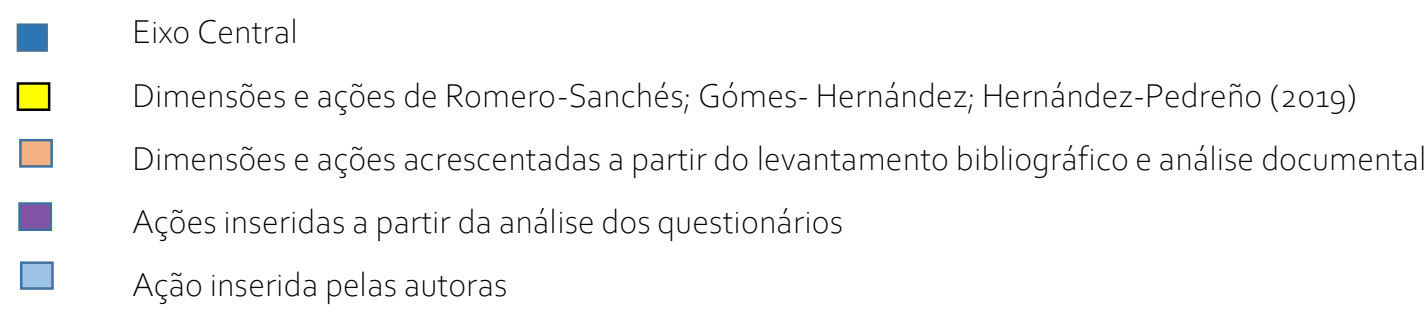

OBSERVAÇÃO: Em negrito estão representadas as Dimensões, os demais retângulos são Ações.

Fonte: Baseado em Almeida Júnior (2013), Alvin; Calixto (2013), Araújo (2009), Barros (2002), Bernardino e Suaiden (2011), Cook; Geldenhuys (2018), Cunha (2003), Cunha; Cavalcante (2008), Dahlsrud (2008), Du Mont (1991), Ferraz; Dumont (2018), IFLA (1994), Milanesi (2013), Moraes; Lucas (2012), Ranganathan (2009), Romero-Sanchés; Gómes-Hernández; Hernández-Pedreño (2019), Tello (2013), Valls (2013).

Ao observar as categorias de ações efetivamente realizadas, é possível observar que elas corroboram com as ações mapeadas na literatura e na análise documental expressas na Figura 2 e que se encaixam bem dentro das dimensões lá identificadas.

Ressalta-se que a Figura 2 mostra-se com uma contribuição desta pesquisa, na medida em que ilustra todas as possibilidades de ações, em suas respectivas dimensões, que podem ser realizadas pelas bibliotecas, a fim de cumprir sua função social, consequentemente assumindo sua responsabilidade social. O que também está detalhado no Quadro 3. 


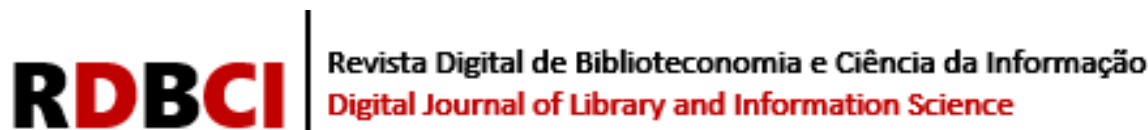

Quadro 3. Dimensões e Ações da Função Social das Bibliotecas Públicas

\begin{tabular}{|c|c|}
\hline DIMENSÕES & AÇÕES \\
\hline Acesso & $\begin{array}{l}\text { Acesso ao acervo } \\
\text { Acesso à tecnologias diversas } \\
\text { Acesso à rede wi-fi } \\
\text { Acesso à computadores } \\
\text { Acesso à leis e normativas }\end{array}$ \\
\hline Inclusão & Promoção da Acessibilidade \\
\hline $\begin{array}{l}\text { Conhecimento e Interlocução Com A } \\
\text { Comunidade }\end{array}$ & $\begin{array}{l}\text { Mapeamento da Comunidade } \\
\text { Coleta de Feedback da Comunidade } \\
\text { Caixa de Sugestões }\end{array}$ \\
\hline Disseminação Informacional & $\begin{array}{l}\text { Uso de Redes Sociais } \\
\text { Divulgações Diversas (ex: novos itens no acervo, eventos, } \\
\text { divulgações de serviços, de bases de dados, etc) } \\
\text { Criação de Tutoriais ou passo a passo (orientações para usuários) }\end{array}$ \\
\hline Preservação Da Memória & $\begin{array}{l}\text { Preservação das histórias da própria comunidade e da biblioteca } \\
\text { Preservação de fotografias e vídeos (comunidade e biblioteca) }\end{array}$ \\
\hline Incentivo A Leitura & $\begin{array}{l}\text { Troca-troca de livros } \\
\text { Promoção do Desenvolvimento Intelectual (ex: indicação de } \\
\text { leituras) } \\
\text { Rodas de Leitura }\end{array}$ \\
\hline Sustentabilidade & $\begin{array}{l}\text { Ações em prol do meio ambiente } \\
\text { Separação do lixo } \\
\text { Eliminação do uso de copos descartáveis }\end{array}$ \\
\hline Perfil Bibliotecário & $\begin{array}{l}\text { Atendimento profissional } \\
\text { Qualidade dos Serviços ofertados (atividades } \\
\text { biblioteconômicas) } \\
\text { Cumprimento da função social } \\
\text { Capacitação permanente } \\
\text { Postura ética } \\
\text { Moral }\end{array}$ \\
\hline Ação Social & $\begin{array}{l}\text { Realização de campanhas sociais (ex: coleta de alimentos) } \\
\text { Promoção da construção cidadã }\end{array}$ \\
\hline Lugar De Aprendizado & $\begin{array}{l}\text { Realização de palestras } \\
\text { Realização de rodas de Conversa } \\
\text { Promoção de reforço Escolar } \\
\text { Realização de preparatório para o ENEM } \\
\text { Oferta de aulas de informática } \\
\text { Oferta de minicursos }\end{array}$ \\
\hline Ações Culturais & $\begin{array}{l}\text { Lugar de encontro } \\
\text { Teatro } \\
\text { Amostras/Exposições } \\
\text { Dança } \\
\text { Música } \\
\text { Encontro de Jogadores } \\
\text { Hora do Conto (uma contação de estórias dramatizada) }\end{array}$ \\
\hline
\end{tabular}

Fonte: elaborado pelas autoras, 2020.

Foi questionado aos bibliotecários sobre a percepção da valorização das ações/serviços ofertados e foi mencionado como resposta que a valorização era perceptível por meio da ocupação crescente e visível do espaço social da biblioteca, pelo uso dos serviços oferecidos, pelo aumento gradativo na participação nos eventos realizados, assim como pelo feedback dado pelos usuários aos profissionais por meio de conversas e comentários. Adicionalmente, todos 


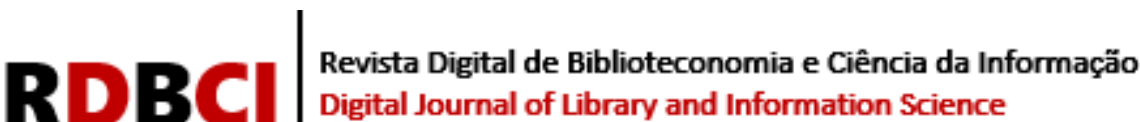

os bibliotecários admitiram que a execução de ações sociais possibilita não apenas a satisfação por parte dos usuários, mas favorece a visibilidade da prática bibliotecária e amplia o fortalecimento do papel social da biblioteca e do bibliotecário. Além de aproximar os bibliotecários de seus usuários e do contex to onde os mesmos estão inseridos, possibilitando a prestação de serviços mais adequados.

Porém, para a execução das ações também foram relatadas dificuldades por parte dos bibliotecários. E, inclusive algumas destas dificuldades impedem o desenvolvimento de algumas categorias de ações na biblioteca. Dentre estes entraves estão a questão do espaço físico como um dos entraves para prática de ações sociais e culturais. Também foram apontadas como dificuldades: o quadro funcional limitado, a falta de estratégias por parte dos gestores para possibilitar a execução das ações, a falta de articulação comunitária, a falta ou limitação no planejamento das ações e eventos, além da sobrecarga de trabalho.

Por fim, questionados sobre quais atividades da prática diária da Biblioteconomia eles achavam que poderiam ser consideradas práticas de RS, os bibliotecários responderam que todas as ações diárias desenvolvidas envolvem RS: o ato de catalogar, classificar, informar, disponibilizar os diversos serviços, disseminar informação, atender às necessidades da comunidade podem ser consideradas atividades com cunho social, especialmente se são realizadas de forma ética e com foco nos usuários. De fato, o atendimento eficaz e a execução com ética e responsabilidade dos diferentes serviços e ações desenvolvidas contribuem na efetivação do papel social da biblioteca, conforme explicitado pelos autores Bernardino e Suaiden (2011), além de terem potencial para atrair a comunidade e criar um vínculo com a mesma.

5. 2 Atuação das Bibliotecas Públicas no Período da Pandemia do Covid-19

A pandemia causada pela Covid-19 foi identificação na China, em dezembro de 2019, sendo declarada como epidemia em janeiro de 2020 e pandemia em março de 2020. No Brasil, o primeiro caso ocorreu na cidade de São Paulo, no dia 26 de fevereiro de 2020.

Diante disso, o Ministério da Saúde (MS) com o intuito de proteger a população adotou diversas medidas, entre elas o distanciamento social, que provocou a suspensão do funcionamento de diversos tipos de estabelecimentos tais como escolas, universidades, lojas, shoppings, fábricas, bibliotecas, entre outros. Tendo sido mantidos apenas os serviços considerados essenciais, entre eles: farmácias, supermercados, hospitais, mercadinhos, etc. Dessa forma, o mundo todo foi surpreendido pela crise social, econômica, política e de saúde mundial causada pela pandemia da Covid-19 (OLIVEIRA et al., 2020).

Devido a todo este contexto e à disseminação rápida da Covid-19, seguindo as orientações da OMS, o Sistema Nacional de Bibliotecas Públicas (SNBP) apresentou algumas medidas a serem adotadas pelas bibliotecas (FUNDAÇÃO BIBLIOTECA NACIONAL, 2020, p.1). Além disso, foram adotadas medidas de isolamento social necessárias para a prevenção e diminuição da propagação do vírus. Assim, as bibliotecas foram obrigadas a cancelar suas atividades presenciais e encerrar as visitas aos seus espaços. E, com isso, muitas precisaram se reinventar, a fim de ofertar serviços e realizar atendimentos e ações por meio do ambiente digital, usando recursos tecnológicos e a internet como principais ferramentas de trabalho.

Para as bibliotecas, assim como diversos outros setores, que não estavam preparados para um trabalho totalmente remoto, muitas adaptações precisaram ser feitas. O que trouxe um grande desafio e dificuldades iniciais, pois a realização de atividades online requer planejamento e disponibilidade de recursos (ex: internet de qualidade e equipamentos computacionais como computador/notebook, câmera, microfone, etc) por parte dos 


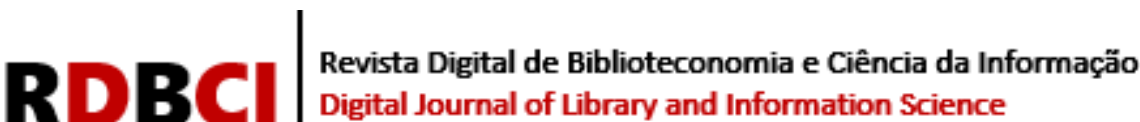

funcionários, além de conhecimento do manuseio/uso de equipamentos, recursos, aplicativos e programas por parte dos envolvidos. Apesar de tudo isto, observou-se que as bibliotecas estudadas passaram a fazer um uso mais intenso das redes sociais (principalmente Facebook e Instagram) para disponibilizar ações educativas, lúdicas e informativas.

Verificou-se que, no período de pandemia, as dimensões da função social (Figura 2) exploradas pelas bibliotecas foram: Incentivo à leitura (ex: contação de histórias, dicas de livros), Disseminação da Informação, Ações Culturais (ex: saraus), Lugar de Aprendizado (ex: lives sobre diversas temáticas ou sobre realização de trabalhos manuais), Sustentabilidade (ex: lives sobre conscientização ambiental e separação de lixo) e Função Social (ex: campanhas de arrecadação de alimentos). A Inclusão não foi praticada nas bibliotecas, uma vez que em suas redes sociais e sites não foram percebidos elementos de acessibilidade. Adicionalmente, a dimensão Perfil Bibliotecário estava sendo atendida apenas parcialmente, visto que muitas atividades do fazer bibliotecário não estavam sendo realizadas remotamente.

A partir do acompanhamento feito é possível mencionar que as bibliotecas poderiam ter utilizado o novo contexto para mapear melhor as necessidades (talvez novas necessidades) dos seus usuários e criar um vínculo maior com eles em meio digital. Também vale mencionar que nem sempre o espaço digital foi bem explorado, visto que cada rede social tem seu estilo e linguagem próprio, não sendo adequado utilizar uma mesma postagem, em um mesmo formato em todas elas e que é preciso que haja atualizações periódicas para manter o interesse dos usuários, o que nem sempre foi atendido pelos bibliotecários. Estes pontos começam a precisar ser contemplados no planejamento das bibliotecas, visto que este novo espaço em que elas precisam ser fazer presentes (o ambiente digital) tem se tornado cada vez mais relevante, requer planejamento (o que postar, quem postar, como postar, entre outros) e gera um trabalho adicional para os bibliotecários envolvidos, visto que as redes sociais não faziam parte das atividades convencionais dos mesmos. O que endossa a necessidade de inventar e se reinventar do bibliotecário e das próprias bibliotecas para ter flexibilidade para se adaptar às mudanças sociais, tecnológicas e às situações adversas e imprevisíveis, como a da pandemia do Covid-19.

\section{CONSIDERAÇÕES FINAIS}

O viés social que permeia a Ciência da Informação vem sendo cada vez mais exigido e explorado. Isto tem destacado a relevância da adaptação às mudanças por parte das bibliotecas e de seus profissionais, uma vez que o perfil dos usuários é dinâmico, o que faz surgir novas necessidades informacionais por parte deles. $\mathrm{O}$ trabalho e ações desenvolvidas pela biblioteca e pelos bibliotecários também tem sido impactados pela evolução tecnológica, que traz novas possibilidades de atuação e de desenvolvimento de ações. Um exemplo claro tem sido a necessidade das bibliotecas se fazerem presentes no ambiente digital por meio de redes sociais, muito utilizadas no contexto atual, em especial, pelo público mais jovens. Este cenário corrobora com o pensamento de Ranganatham (2009), ao identificar a biblioteca como um organismo vivo, que deve estar em constante transformação, juntamente com aqueles que a utilizam, evidenciando o papel social que é exercido pelas bibliotecas e seus bibliotecários.

Analisar a RS das bibliotecas públicas e a função social desempenhada por elas trouxe a possibilidade de refletir sobre a relevância para a sociedade e, especificamente, para os usuários das bibliotecas, das ações por elas praticadas. Também trouxe a possibilidade de observar que a maioria das práticas de RS já fazem parte do fazer bibliotecário, já são atividades que são desempenhadas por este profissional em seu cotidiano e são mencionadas na literatura da área de CI e em normativas. Além disso, as dimensões éticas, políticas, educacionais e 


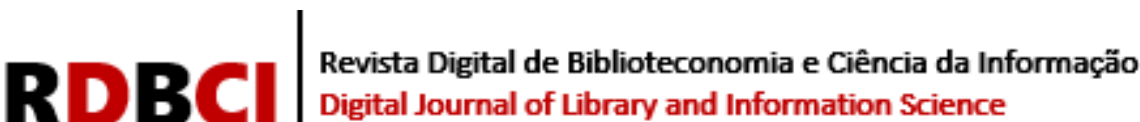

culturais desempenhadas nas atividades biblioteconômicas são contempladas nas dimensões de RS mapeadas nesta pesquisa. O que vem ao encontro do código de ética do Bibliotecário e de sua responsabilidade social na construção de uma sociedade ética, considerando as singularidades e as questões sociais pertinentes.

Apesar do mapeamento de ações ter sido amplo, esta pesquisa tem como limitação a quantidade de bibliotecas estudadas e o fato delas fazerem parte de uma única cidade: o Recife. Pois bibliotecas públicas que possuam contextos diferentes, sejam de outras cidades ou regiões podem apresentar um conjunto de ações relacionadas à RS ainda mais amplo. Ainda assim, ressalta-se que esta pesquisa traz este mapeamento inicial de dimensões e ações relacionadas à responsabilidade social e à função social da BP como contribuição, uma vez que não há similar na literatura consultada, e a metodologia de trabalho pode ser tomada como base para uma pesquisa mais ampla em bibliotecas espalhadas por uma região ou por todo o território nacional.

Além disso, indica-se como sugestão de trabalho futuro analisar o quanto a formação curricular dos bibliotecários os prepara para a execução das ações relacionadas à RS. Pois em conversa com alguns bibliotecários durante a realização da pesquisa, muitos aprenderam a realizar as ações, realizando-as. Porém, relataram que, inicialmente, não se sentiam preparados para tanto ou sequer visualizavam algumas das ações como possiblidades para cumprir a função social da sua profissão e contribuir com o papel da biblioteca pública

Diante do mapeamento de dimensões e ações realizado na pesquisa, considera-se que é notória a responsabilidade social tanto do bibliotecário, quanto da biblioteca pública para que esta possa ser um espaço propício à promoção da leitura, da inclusão social e digital, e da cidadania. Destaca-se, adicionalmente, que a responsabilidade social também se faz presente na ética do profissional bibliotecário, quando ele desempenha seu papel social por meio das diferentes práticas biblioteconômicas, realizadas de forma ética, fazendo com que os serviços ofertados estejam em consonância com as necessidades dos usuários da biblioteca onde atua.

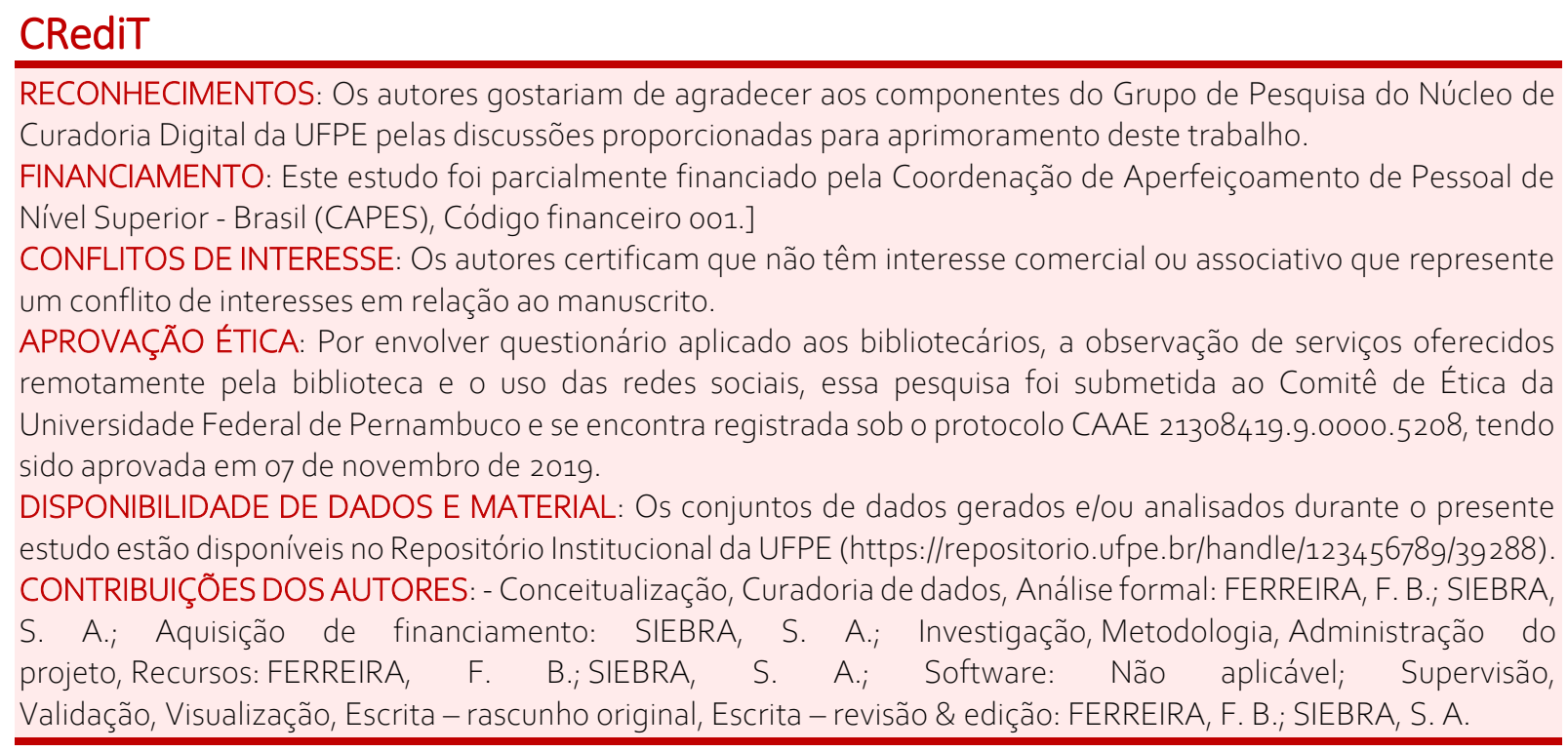




\section{RDBCI}

\section{REFERÊNCIAS}

ARAÚJO, Carlos Alberto Ávila. Correntes Teóricas da Ciência da informação. Ciência da Informação, Brasília, DF, v. 38, n.3, p. 192-204, set./dez. 2009. Disponível em: https://www.scielo.br/j/ci/a/qhsrgPL7T6RbKKVbMwrPMNb/?format=pdf\&lang=pt. Acesso em: 27 ago. 2021.

ASHLEY, Patrícia Almeida. Ética e responsabilidade social nos negócios. São Paulo: Atlas, 2003. 205 p. ISBN 9788502050679.

ABNT - ASSOCIAÇÃO BRASILEIRA DE NORMAS TÉCNICAS. NBR ISO 26000. Diretrizes de Responsabilidade social. Rio de Janeiro: ABNT, 2010. Disponível em: http://www.inmetro.gov.br/qualidade/responsabilidade_social/iso26000.asp. Acesso em: 27 ago. 2021.

BARDIN, Laurence. Análise de conteúdo. Lisboa: Edições 70, 2009. 288 p. ISBN 9789724415062.

BARROS, Paulo. A biblioteca pública e sua contribuição social para a educação do cidadão. Ijuí: Ed. Unijuí, 2002. 199 p. ISBN 9788574292878.

BERNARDINO, Maria Cleide Rodrigues.; SUAIDEN, Emir José. O papel social da biblioteca pública na interação entre informação e conhecimento no contexto da ciência da informação. Perspectivas em Ciência da Informação, Minas Gerais, v.16, n.4, p.29-41, out./dez. 2011. Disponível em: https://www.scielo.br/pdf/pci/v16n4/v16n4a04.pdf. Acesso em: 27 ago. 2021.

BIBLIOTECA PÚBLICA DO ESTADO DE PERNAMBUCO. Histórico. Recife: [S.n], 2020. Disponível em: http://www.biblioteca.pe.gov.br/?pag=1\&men=3. Acesso em: 27 ago. 2021.

BICALHO, Aline Gualtieri Dolabela. et al. Responsabilidade social das Empresas: a contribuição das universidades. São Paulo: Peirópolis: Instituto Ethos, 2003.

CARROLL, Archie B. Three- Dimensional Conceptual. Model of. Corporate Performance. The Academy of Management Review, [S.1], v. 4, n. 4, p. 497- 505, out. 1979. Disponível em: https://bit.ly/39jpNx3. Acesso em: 27 ago. 2021.

CARROLL, Archie B.; SHABANA, Kareen M. The business case for corporate social responsibility: a review of concepts, research and practice. International Journal of Management Reviews, São Paulo, v. 12, n.1, p. 85-105, 2010. Disponível em: https://onlinelibrary.wiley.com/doi/10.1111/j.1468-2370.2009.00275.x. Acesso em: 27 ago. 2021.

CAPURRO, Rafael.; HJORLAND, Birger. O conceito de informação. Perspectivas em Ciência da Informação, Belo Horizonte, v. 12, n. 1, p. 148- 207, 2007. Disponível em: http://portaldeperiodicos.eci.ufmg.br/index.php/pci/article/view/54. Acesso em: 27 ago. 2021. 


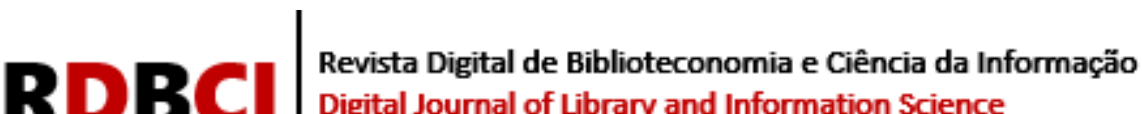 \\ Digital Journal of Library and Information Science}

CONSELHO FEDERAL DE BIBLIOTECONOMIA. Código de Ética e Deontologia do Bibliotecário Brasileiro. Brasília: CFB, 2018. Disponível em: https://bit.ly/3keFcFi. Acesso em: 27 ago. 2021.

COOK, Gretha.; GELDENHUYS, Dirk J. The experiences of employees participating in organisational corporate social responsibility initiatives. SA Journal of Industrial

Psychology/SA Tydskrif vir Bedryfsielkunde, Johannesburg, v. 44, n. 0, p. 1- 10, 2018. Disponível em: https://bit.ly/3ziuxxN. Acesso em: 27 ago. 2021.

CUNHA, Murilo Bastos.; CAVALCANTI, Cordélia Robalinho de Oliveira. Dicionário de biblioteconomia e arquivologia. Brasília, DF:Briquet de Lemos, 2008. 451 p. ISBN 978858563735 .

CUNHA, Miriam Vieira. O papel social do bibliotecário. Encontros Bibli: Revista Eletrônica de Biblioteconomia e Ciência da Informação, Florianópolis, n. 15, $1^{\circ}$ sem. 2003. Disponível em: http://www.encontros-bibli.ufsc.br/. Acesso em: 27 ago. 2021.

DAHLSRUD, Alexander. How corporate social responsability is defined: An analysis of 37 definitions. Corporate Social Responsability and Environmental Management, [S.1], v. 15, n. 1, p. 1- 13, 2008. Disponível em: https://bit.ly/3CoC401. Acesso em: 27 ago. 2021.

DANTAS, Esdras Renan.; GARCIA, Joana Coeli Ribeiro. Do tradicional ao atual conceito de Responsabilidade social da Ciência da Informação. Biblionline, João Pessoa, v. 9, n. 2, p. $3-$ 18, 2013. Disponível em:

https://periodicos.ufpb.br/ojs2/index.php/biblio/article/download/15281/10157. Acesso em: 27 ago. 2021.

DU MONT, Rosemary Ruhig. Ethics in Librarianship: a management model. Library Trends, Maryland, v. 40, n.2, p. 201-2015,1991. Disponível em: https://www.ideals.illinois.edu/bitstream/handle/2142/7767/librarytrendsv40i2c_opt.pdf. Acesso em: 27 ago. 2021.

FERRAZ, Marina Nogueira.; DUMONT, Lígia Maria Moreira. Dimensões essenciais das bibliotecas públicas. Ci. Inf. Rev., Maceió, v.5, n.1 p. 11- 28, jan./abr. 2018. Disponível em: https://www.seer.ufal.br/index.php/cir/article/view/4812/0. Acesso em: 27 ago. 2021.

FERREIRA, Aurélio Buarque de Holanda. Dicionário da Língua Portuguesa Miniaurélio. 4.ed. Rio de Janeiro: Nova Fronteira, 2000. 896 p. ISBN 8574729604.

FERREIRA, Fernanda Bernardo. A Biblioterapia como instrumento de Responsabilidade social dos profissionais Bibliotecários: uma visão de alunos Pré- concluintes. 2015. Trabalho de conclusão de Curso (Monografia)- Universidade Federal da Paraíba, João Pessoa, 2015. Disponível em: https://bit.ly/3Ezf40f. Acesso em: 27 ago. 2021.

FERREL, O. C. et al. Ética: dilemas, tomadas de decisões e casos. Rio de Janeiro: Reichamnn \& Affonso Ed., 2001. 420 p. ISBN 9788587148490.

FONSECA, Juliana Soares da.; GARCIA, Joana Coeli Ribeiro. Responsabilidade ética e social do profissional da informação. BIBLIONLINE, João Pessoa, v. 5, n. 1/2, p. 2009. 
| $\mid \begin{aligned} & \text { Revista Digital de Biblioteconomia e Ciência da Informação } \\ & \text { Digital Journal of Library and Information Science }\end{aligned}$

Disponível em:

https://www.brapci.inf.br/_repositorio/2010/11/pdf_6d3ce8ae6e_0013250.pdf. Acesso em: 27 ago. 2021.

FUNDAÇÃO BIBLIOTECA NACIONAL. Sistema Nacional de Bibliotecas Públicas. Novas orientações a bibliotecas públicas e comunitárias covid- 19. Brasília: FBN, 2020.

Disponível em: https://bit.ly/3hXV5yD. Acesso em: 28 jun. 2020.

FRANCO, Maria Laura Puglisi Barbosa. Análise de conteúdo. Brasília, DF: Liber Livro, 2005. 79 p. ISBN 8598843326.

GARCIA, Joana Coeli Ribeiro.; TARGINO, Maria das Graças.; DANTAS, Esdras Renan. Conceito de Responsabilidade social da Ciência da Informação. Inf. Inf., Londrina, v. 17, n. 1, p.1 - 25, jan./jun. 2012. Disponível em: https://brapci.inf.br/index.php/res/v/34029. Acesso em: 27 ago. 2021.

IFLA - INTERNATIONAL FEDERATION OF LIBRARY ASSOCIATIONS AND INSTITUTIONS. Manifesto da IFLA/UNESCO sobre bibliotecas públicas, 1994. 1994. Disponível em: https://bit.ly/2XjMdM6. Acesso em: 27 ago. 2021.

INSTITUTO ETHOS. Indicadores ethos de Responsabilidade social empresarial. São Paulo: Instituto Ethos, 2007. Disponível em: https://bit.ly/2XpYiiY. Acesso em: 27 ago. 2021.

KAUARK, Fabiana.; MANHÃES, Fernanda Castro.; MEDEIROS, Carlos Henrique. Metodologia da pesquisa: guia prático. Itabuna: Via Litterarum, 2010. 96 p. ISBN 9788598493978.

LE COADIC, Yves- François. A Ciência da Informação. 2. ed. Brasília: Briquet de Lemos, 2004. 124 p.

LOURENÇO, Alex Guimarães.; SCHRODER, Debora de Souza. Vale a pena investir em responsabilidade social? Stakeholders, ganhos e perdas. In: Responsabilidade social das empresas: A contribuição das universidades. v. 2. 2. ed. São Paulo: Peirópolis, Instituto Ethos, 2003. 289 p. ISBN 9788575961483.

MACHADO FILHO, Cláudio Antônio Pinheiro. Responsabilidade social e Governança: o debate e as implicações: Responsabilidade social, instituições, governança e reputação. São Paulo: Cegage, 2013. 192 p. ISBN 9788522105137.

MACHADO, Elisa.; ELIAS JUNIOR, Alberto.; ACHILLES, Daniele. A biblioteca pública no espaço público: estratégias de mobilização cultural e atuação sócio- política do bibliotecário. Perspectivas em Ciência da Informação, Belo Horizonte, v.14, número especial, p.115127, out./dez. 2014. Disponível em: https://bit.ly/31xIMde. Acesso em: 27 ago. 2021.

MENDONÇA, Ricardo Rodrigues Silveira de. As dimensões da Responsabilidade social: uma proposta de instrumento para avaliação. In: Responsabilidade social das Empresas: a contribuição das universidades. São Paulo: Peirópolis: Instituto Ethos, 2003. 289 p. ISBN 9788575961483.

RDBCl: Rev. Dig. Bibliotec e Ci. Info. / RDBCl: Dig. J. of Lib. and Info. Sci. | Campinas, SP | v.19| e021022 | 2021 


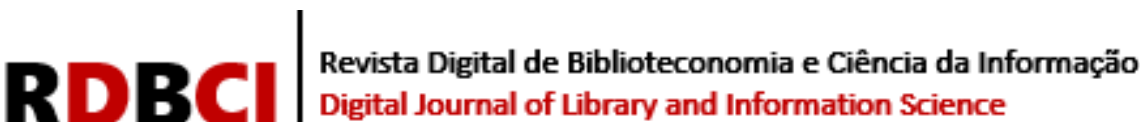

MILANESI, Luiz. Biblioteca. 3. ed. Cotia, SP: Ateliê, 2013. 120 p. ISBN 9788574806419.

MISCHIATI, Ana Cristina.; VALENTIM, Marta Lígia Pomim. Reflexões sobre a ética e a atuação profissional do Bibliotecário. Transinformação, Campinas, v.17, n.3, p. 209-220, set./dez., 2005. Disponível em: https://bit.ly/3Ep40SZ. Acesso em: 27 ago. 2021.

MORAES, Marielle Barros de.; LUCAS, Elaine de Oliveira. A Responsabilidade social na formação do bibliotecário brasileiro. Em Questão, Porto Alegre, v. 18, n. 1, p. 109- 124, 2012. Disponível em: https://seer.ufrgs.br/EmQuestao/article/view/24107. Acesso em: 27 ago. 2021.

OLIVEIRA, Wanderson Kleber de.; DUARTE, E.; FRANÇA, Giovanny Vinícius Araújo de.; GARCIA, Leila Posenato. Como o Brasil pode deter COVID 19. Epidemiologia Serv. Saúde, Brasília, v. 29, n. 2, p. 1-8, 2020. Disponível em: https://bit.ly/2XB1sk6. Acesso em: 27 ago. 2021.

PAJO, Karl.; LEE, Louise. Corporate sponsored volunteering: A work design perspective. Journal of Business Ethics, [S.1.], v. 99, p. 467-482, 2010. Disponível em: https://bit.ly/3lzga36. Acesso em: 27 ago. 2021.

PARRA, Marcelo Fernando Lopes. Responsabilidade Corporativa: entre o social e o regulado estudo de um setor da siderurgia brasileira. 224f. 2004. Tese (Doutorado em Administração) - Escola Brasileira de Administração Pública e de Empresas, Rio de Janeiro, 2004. Disponível em: https://bit.ly/3Ah7YuD. Acesso em: 27 ago. 2021.

PAULA, Sílvio Luiz de. Comunicação organizacional e responsabilidade social em instituições de ensino superior de Pernambuco: o uso de ferramentas de comunicação para a construção da impressão de organização socialmente responsável. 2010. 164 f. Dissertação (Mestrado em Administração) - CCSA, Universidade Federal de Pernambuco, Recife, 2010. Disponível em: https://repositorio.ufpe.br/handle/123456789/1210. Acesso em: 27 ago. 2021.

RANAGANATHAN, Shiyali Ramamrita. As cinco leis da Biblioteconomia. Tradução de: Tarcisio Zandonade. Brasília, DF: Briquet de Lemos, 2009. 362 p. ISBN 9788585637385.

RECIFE. SECRETARIA DE CULTURA DO RECIFE. FUNDAÇÃO DE CULTURA CIDADE DO RECIFE. Áreas Culturais. Recife: SCR, [2020]. Disponível em: http://www.recife.pe.gov.br/fccr/bibliotecas.php. Acesso em: 27 ago. 2021.

ROMERO- SANCHÉS, Eduardo.; GÓMES- HERNÁNDEZ, José-Antônio.; HERNÁNDEZ- PEDREÑO, Manuel. La función social de las bibliotecas públicas: la perspectiva professional. RICI: R.Ibero- amer. Ci. Inf., Brasília, v. 12, n. 2, p. 341-360, maio/ago. 2019. Disponível em: https://doi.org/10.26512/rici.v12.n2.2019.20642. Acesso em: 27 ago. 2021.

SARACEVIC, Tefko. Ciência da Informação: origem, evolução e relações. Perspec. Ci. Inf., Belo Horizonte, v. 1, n. 1, p. 41-62, jan./jun. 1996. Disponível em: http://portaldeperiodicos.eci.ufmg.br/index.php/pci/article/view/235. Acesso em: 27 ago. 2021. 


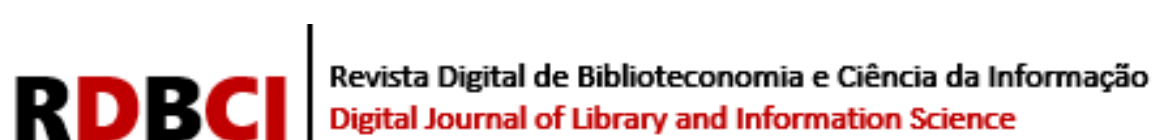

SILVA, Elieny do Nascimento. A responsabilidade social da biblioteconomia nas ações de extensão universitária. 2017. 249 f. Tese (Doutorado em Ciência da Informação) Universidade Federal da Bahia, Salvador, 2017. Disponível em:

https://repositorio.ufba.br/ri/handle/ri/25357. Acesso em: 27 ago. 2021.

TELLO, Felipe Meneses. Bibliotecas y Sociedad: el paradigma social de la biblioteca pública. Investigación Bibliotecológica: Aschivonomía, Bibliotecología e Información, México, v.27, n. 61, p. 157-173, 2013. Disponível em: http://revib.unam.mx/ib/index.php/ib/article/view/42818/51243. Acesso em: 27 ago. 2021.

VAINSEnCHER, Semira Adler. A Biblioteca Pública de Pernambuco. Recife: Pesquisa Escolar Online, Fundação Joaquim Nabuco, 2004. Disponível em: https://pesquisaescolar.fundaj.gov.br/pt-br/artigo/biblioteca-publica-de-pernambuco/. Acesso em: 27 ago. 2021.

VALLS, Álvaro Luiz Montenegro. O que é ética. São Paulo: Brasiliense, 2013. 82 p. ISBN 9788511011777.

VALLAEYS, François. O que significa responsabilidade social universitária? Estudos: Revista da ABMES, Brasília, v. 24, n. 36, p. 35- 56, jun. 2006. Disponível em: https://abmes.org.br/arquivos/publicacoes/Estudos36.pdf. Acesso em: 15 abr. 2020.

VELOSO, Letícia Helena Medeiros. Ética, valores e cultura: especificidades do conceito de Responsabilidade social corporativa. In: ASHLEY, P. Ética e Responsabilidade social nos negócios. 2.ed. São Paulo: Saraiva, 2005. 334 p. ISBN 9788502050679.

VIJESH, Pathirikkal Vijayan de.; MOHANAN, Neethu. Social Responsibilities of academic Libraries: Rajagiri College of social Sciences Library: Kalamassery kerala: a case Study. Publisher: Astral, 2018. 


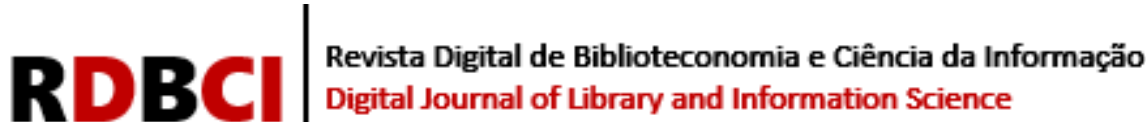

